\title{
RETHINKING THE DIGITAL DIVIDE: MEDIATION ROLE OF COMPUTER SELF-EFFICACY
}

\author{
Arief Rahman \\ Universitas Islam Indonesia \\ e-mail: ariefrahman@uii.ac.id
}

\begin{abstract}
The main purpose of this research is to develop an understanding of the mediating role of computer self-efficacy in the relationship between access to information and communication technology (ICT) and e-government usage. To achieve its objectives, this research applied a quantitative survey and analyse the results using PLS-based structural equation approach. The survey was involving 237 e-government users in Indonesia. The findings confirm that computer self-efficacy has a partial mediating role on the relationship between access to ICT and e-government use. The study provides evidence on the importance of computer self-efficacy in improving e-government use. Discussions on the implications for practice as well as theory are presented.
\end{abstract}

Keywords: e-government, self-efficacy, access, digital divide, mediation

\begin{abstract}
Abstrak
Tujuan utama dari penelitian ini adalah untuk mengembangkan pemahaman tentang peran mediasi self-efficacy komputer dalam hubungan antara akses ke teknologi informasi dan komunikasi (ICT) dan penggunaan e-government. Untuk mencapai tujuannya, penelitian ini diterapkan survei kuantitatif dan menganalisis hasil menggunakan PLS berbasis pendekatan persamaan struktural. Survei ini melibatkan 237 pengguna e-government di Indonesia. Temuan mengkonfirmasi bahwa self-efficacy komputer memiliki peran mediasi parsial pada hubungan antara akses ICT dan penggunaan e-government. Studi ini memberikan bukti tentang pentingnya self-efficacy komputer dalam meningkatkan penggunaan e-government. Diskusi tentang implikasi untuk praktek serta teori disajikan.
\end{abstract}

Kata kunci: e-government, efikasi diri, akses, kesenjangan digital, mediasi

\section{INTRODUCTION}

Information and communication technology (ICT) is important for reducing discrimination based on lack of access to information and timely response to the matters influencing individuals' personal and community welfare (Coco and Jolly 2003). Therefore government agencies across the world are facilitating the uptake of ICT for disadvantaged people. An interesting vignette is presented by Warschauer (2003) in describing such facility. The government of New Delhi in 2000 provided computer access in slum areas for city's street children. A project, known as Hole-in-the-Wall, allowed the street children to have 24-hour access to computer and internet. Beside the internet connection through dial up access, the computers were also equipped with some essential programs, such as Microsoft Office and Paint. Without any instructor whatsoever, the children may learn how to use computer and internet at their own pace and speed.

However, the result indicated that the access to internet was so seldom and majority of the children used the computer to draw with paint programs or playing games. The failure of the project caused by no special education had been made available for those children. Some parents expressed their concern that the absence of instruction took away the project's value. Some other even raised negative feelings about the project, complaining that the computers distracted their children from their homework and schoolwork. 
The story above represents the nature of incomplete policies by many governments to overcome digital divide based on underlying understanding that the main problem is inequality of access, especially physical access to ICT. Thus, scholars such as Dewan, Ganley, and Kraemer (2005); Wei et al. (2010); Hsieh, Rai, and Keil (2009) suggest broader and more comprehensive understanding of the problem of digital divide.

The main aim of this study is to examine the mediation effect of computer selfefficacy on the impact of access to ICT on egovernment use. In doing so, this study compares the $t$-values in PLS-graph between models, with and without the trust in e-government as a mediator, and the Sobel test. The research was conducted in Indonesia, involving 237 respondents of e-government users.

The structure of this paper is divided into six sections, in following manner: introduction and research objective; theoretical background and model development; research method and findings; and discussion, which is written in integration with implications and conclusion.

\section{LITERATURE REVIEW AND HYPO- THESES DEVELOPMENT}

\section{Social Cognitive Theory}

This research relies on Social Cognitive Theory (Bandura 1977, 2001) as the underlying theoretical foundation. The theory suggests that individuals possess a self-belief system that allows them to take control over their cognitive process. The key of the systems is self-efficacy, which refers to "the belief in one's capability to organize and execute the courses of action required managing prospective situations" (Bandura 1977, p. 2). The theory operates within a causal model of triadic reciprocity, where (a) personal factors in the form of cognition, affect, and biological events, (b) environmental factors, and (c) behavior interact one another (Bandura 2001). Contextualized in this research, personal factor is represented by computer self-efficacy, while the environmental factor by access to ICT and behavior factor include the use of ICT. Thus the central aim of this study is that the access to ICT influences behavior in using ICT directly as well as through the mediating role of computer self-efficacy (Figure 1). Behavior in using ICT is represented by egovernment use in this study.

\section{Access to ICT}

There is a sizeable difference in internet access and home-computer ownership across and within countries. As reported by UN (2010), more than 50\% residents in developed countries have internet access and own a personal computer. On the other hand, in some LDCs (least developing countries), the number is far below 5\%. In terms of region, Europe is the most connected region whereas Africa is the least.

Previous studies concluded that the access to ICT was a substantial factor of ICT use (eg. Dewan, Ganley, and Kraemer 2005; Wei et al. 2010; Ynalvez and Shrum 2006; Hsieh, Rai, and Keil 2009). Even access divide is the focus of the most digital divide research (Rahman and Quaddus 2012). On the other hand, studies by Wei et al. (2010) and Dewan and Riggins (2005) found that access to ICT is a significant determinant for computer self-efficacy. In this study, the dimensions of access to ICT are presented in Table 1 below.

Table 1: Dimensions of access to ICT

\begin{tabular}{lll}
\hline Item & Dimensions & Reference \\
\hline ACC1 & Computer availability at home & (Wei et al. 2010) \\
ACC2 & Internet connection at home & (Agarwal, Animesh, and Prasad 2009) \\
ACC3 & Easiness to access ICT & (Ynalvez and Shrum 2006) \\
ACC4 & Comfortable to access ICT & \\
\hline
\end{tabular}




\section{Computer Self-Efficacy}

Self-efficacy can be defined as a belief of the individuals in their capability to execute a particular task. Self-efficacy may not reflect actual competence. Scholars in some fields including information systems have applied the concept widely, although originally Bandura (1977) developed the theory of self-efficacy for treating severely phobic. In information systems, computer self-efficacy has been investigated (eg. Marakas, Yi, and Johnson 1998; Compeau, Higgins, and Huff 1999; Wei et al. 2010). The results concluded that self-efficacy was a significant predictor of attitudes and behavior. The dimensions of computer self-efficacy in this research are described in Table 2.

\section{E-Government Use}

This research intends to investigate relationship among access to ICT, computer selfefficacy and the use of ICT in e-government context, based on the reason that this issue is fundamental for the government in order to develop e-government systems, which focus on citizen. The understanding of the digital divide might also the first step to improve egovernment readiness in Indonesia.

E-Government can be defined as ICT use to improve the access to government services and enhance the delivery of government services and operations. The main objective of e-government systems are for the advantage of business, citizens, and other stakeholders
(Srivastava and Teo 2007). Because of its importance, UN encourages all countries to develop e-government systems. However, developing and applying e-government system is not just simply transferring the system from one country to another. In other words, implementing e-government system needs some additional efforts (Schuppan 2009). Government needs to adjust with the needs of its citizens, since they are the substantial stakeholder for government (Davison, Wagner, and $\mathrm{Ma}$ 2005). e-Government use by its citizens is substantial indicator for the success of egovernment systems. Table 3 presents the dimensions of e-government use.

Based on the discussion above, the following hypothesis is proposed:

H1: Computer self-efficacy has a mediating role between access to ICT and e-government use.

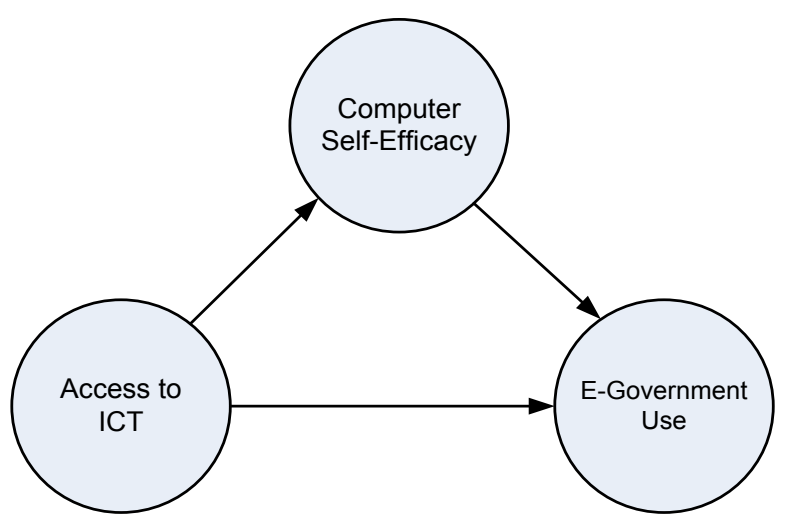

Figure 1: Research model

Table 2: Dimensions of computer self-efficacy

\begin{tabular}{lll}
\hline Item & Dimensions & Reference \\
\hline CSE1 & Confidence in using ICT & (Wei et al. 2010; Hsieh, Rai, and Keil 2009) \\
CSE2 & Difficulty in using ICT & (Wei et al. 2010) \\
CSE3 & Comfortable in using ICT & (Wei et al. 2010; Hsieh, Rai, and Keil 2009) \\
CSE4 & Sure be able to use ICT & (Wei et al. 2010) \\
CSE5 & Able to operate, even if no one tells & (Wei et al. 2010; Hsieh, Rai, and Keil 2009) \\
\hline
\end{tabular}

Table 3: Dimensions of e-government use

\begin{tabular}{lll}
\hline Item & Dimensions & Reference \\
\hline USE1 & Number of use & (DeLone and McLean 2003) \\
USE2 & Number of transactions completed & (Taylor and Todd 1995) \\
USE3 & Using e-government system is a good idea & . \\
\hline
\end{tabular}




\section{RESEARCH METHODOLOGY}

To verify the research model (Figure 1) and hypothesis presented above, data was collected via a survey. In order to draw up adequate survey questions, the researcher carried out literature review and constructed the dimensions listed in Table 1-3. Each question was measured based on 6-point scale.

In conducting the empirical analysis, 354 copies of questionnaires were directly distributed targeting subjects who had used egovernment systems provided by local governments. As a result, 251 questionnaires were retrieved. To find out any errors in the form of invalid data, such as incomplete responses or missing values, a review was carried out. As a result, 14 questionnaires were found to be incomplete or, 237 questionnaires were usable in this research. Table 4 presents the demographic profile of the respondents.

To perform data analysis, the Partial Least Square (PLS) approach to Structural Equation Modeling (SEM) was used. PLS is a po- werful tool of analysis because of the minimum requirements on measurement scales, sample size and residual distributions (Wold 2006).

\section{RESULTS AND DISCUSSION}

\section{Measurement Assessment}

Composite reliability (CR) analysis was conducted to verify convergent validity and discriminant validity. Values greater than 0.70 in $\mathrm{CR}$ imply that the construct retains both its internal consistency and convergent validity (Hair, Ringle, and Sarstedt 2011). The factor loading and Average Variance Extracted (AVE) were also examined to determine the convergent validity. The criteria for the acceptable level of convergent validity is individual item factor loading greater than 0.60 and an AVE greater than 0.50 (Gefen, Straub, and Boudreau 2000). Table 6 and 7 summarize the factor loadings, CR and AVE of the group. All factor loading, CR and AVE in this measurement model turned out to be acceptable.

Table 4: Demographic profile of the respondents

\begin{tabular}{lcccccccc}
\hline \multirow{2}{*}{ Profile } & \multicolumn{2}{c}{ Gender } & \multicolumn{2}{c}{ Age group } & \multicolumn{2}{c}{ Residential place } & \multicolumn{2}{c}{ Education } \\
\cline { 2 - 8 } & Male & Female & $<\mathbf{4 0}$ & $>\mathbf{4 0}$ & City area & Remote & $<$ UG & $\geq$ UG \\
\hline Percentage & $78 \%$ & $22 \%$ & $69 \%$ & $31 \%$ & $71 \%$ & $29 \%$ & $23 \%$ & $77 \%$ \\
Frequency & 184 & 53 & 164 & 68 & 168 & 69 & 55 & 182 \\
\hline
\end{tabular}

Table 5: Cross loading matrix

\begin{tabular}{lcrr}
\hline & USE & ACCES & \multicolumn{1}{c}{ CSE } \\
\hline USE_1 & $\mathbf{0 . 9 1}$ & 0.63 & 0.59 \\
USE_2 & $\mathbf{0 . 7 9}$ & 0.48 & 0.48 \\
USE_3 & $\mathbf{0 . 8 1}$ & 0.58 & 0.61 \\
ACCE_1 & 0.22 & $\mathbf{0 . 7 5}$ & 0.53 \\
ACCE_2 & 0.34 & $\mathbf{0 . 8 2}$ & 0.64 \\
ACCE_3 & 0.75 & $\mathbf{0 . 9 1}$ & 0.81 \\
ACCE_4 & 0.76 & $\mathbf{0 . 9 3}$ & 0.84 \\
CSE_1 & 0.54 & 0.73 & $\mathbf{0 . 8 8}$ \\
CSE_2 & 0.63 & 0.81 & $\mathbf{0 . 9 3}$ \\
CSE_3 & 0.64 & 0.71 & $\mathbf{0 . 9 2}$ \\
CSE_4 & 0.66 & 0.84 & $\mathbf{0 . 9 3}$ \\
CSE_5 & 0.66 & 0.83 & $\mathbf{0 . 9 3}$ \\
\hline
\end{tabular}

Table 6: Discriminant validity

\begin{tabular}{lccc}
\hline & CSE & USE & ACCE \\
\hline CSE & $\mathbf{0 . 8 6 2}$ & & \\
USE & 0.667 & $\mathbf{0 . 7 0 3}$ & \\
ACCE & 0.651 & 0.675 & $\mathbf{0 . 7 3 1}$ \\
\hline
\end{tabular}


Research Model Assessment - Testing the Mediation Role of Computer Self-Efficacy

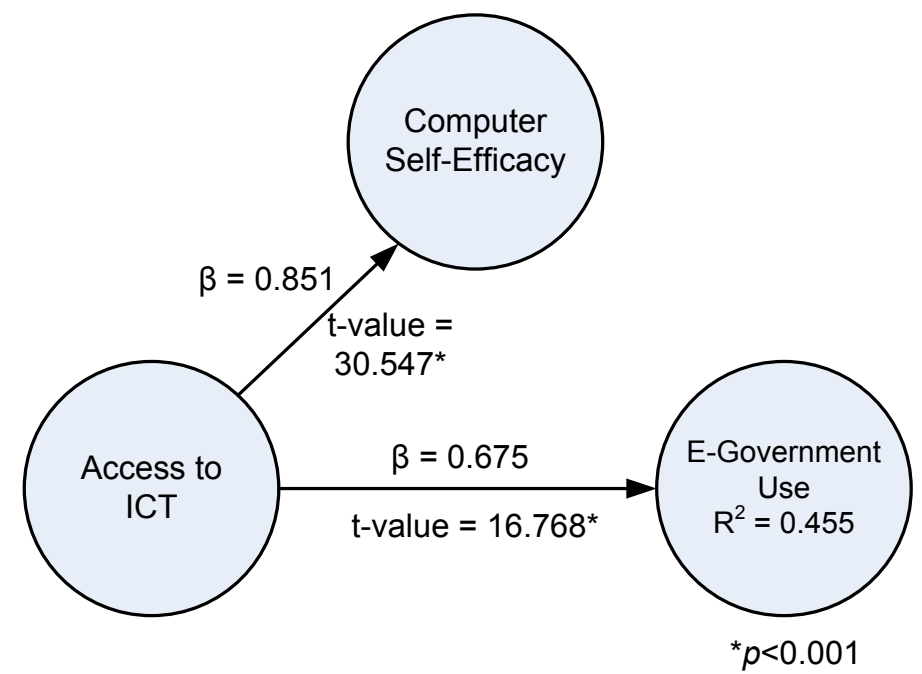

Figure 2: Data analysis result of a model without a mediator

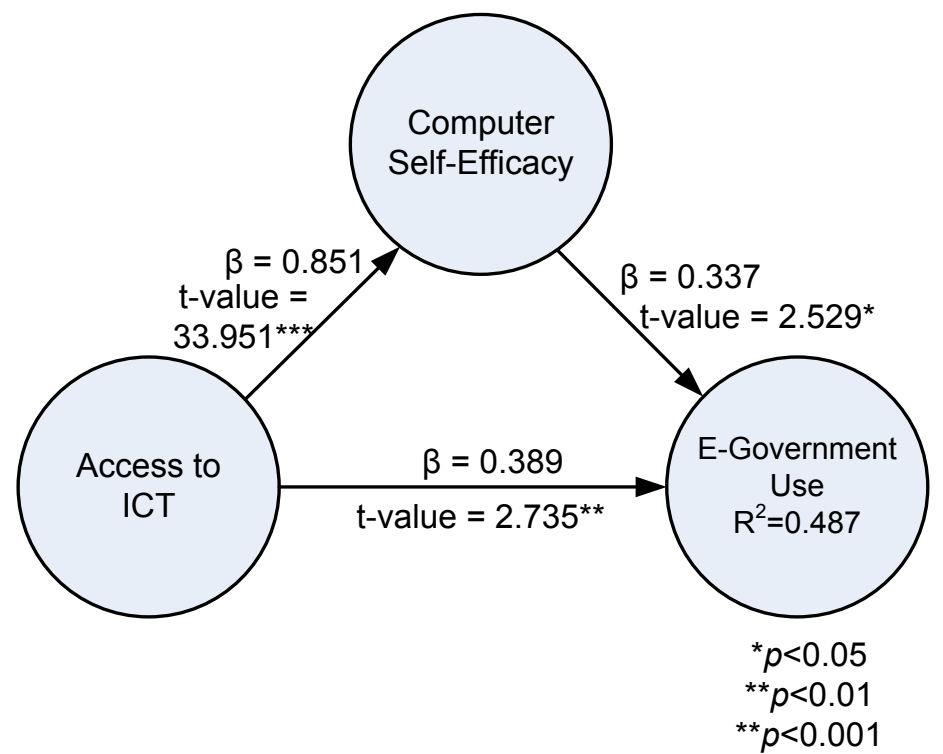

Figure 3: Data analysis result of a model with a mediator

Table 7: Comparison of $t$-value

\begin{tabular}{|c|c|c|c|c|}
\hline \multicolumn{4}{|c|}{$t$-value } & \multirow{3}{*}{ Mediation effect } \\
\hline \multicolumn{2}{|c|}{$X \rightarrow Y$} & \multirow{2}{*}{$\mathbf{M} \rightarrow \mathbf{Y}$} & \multirow{2}{*}{$\mathbf{X} \rightarrow \mathbf{M}$} & \\
\hline Without M & With M & & & \\
\hline $16.768 * * *$ & $2.735^{* *}$ & $2.529 *$ & $33.951 * * *$ & Partial mediation \\
\hline
\end{tabular}

In this research, mediation hypotheses were tested using a statistical technique suggested by Baron and Kenny (1986). Baron and Kenny (1986) suggested that a given variable might function as a mediator (M), if the following conditions held: (1) a significant rela- tionship existed between the independent variable (X) and the dependent variable (Y); (2) a significant relationship existed between $\mathrm{X}$ and $\mathrm{M}$; and (3) in the presence of a significant relationship between $\mathrm{M}$ and $\mathrm{Y}$, the previous relationship between $\mathrm{X}$ and $\mathrm{Y}$ was no longer 
significant or the strength of the relationship was significantly decreased. From Table 7 we can learn that the $t$-value for the relationship of access to ICT (X) and e-government use (Y) with the mediation effect of computer self-efficacy (M) drops to 2.735 from 16.768 without mediation effect. The result indicates that computer self-efficacy has a partial mediation role in the relationship between access to ICT and e-government use.

The assessment of the significance of the reduction of the relationship between the independent and dependent variables cannot be assessed from the coefficient. Rather it has to be mathematically proven. The Sobel test (Sobel 1982) has been a traditional method of testing the significance of mediation effects. The Sobel test was used in this research because it was the most widely employed. The significance was measured by the following formula:

$z$-value $=a * b / S Q R T\left(b^{2} *_{s_{a}}+a^{2} *_{s_{b}}{ }^{2}\right)$

The formula required the unstandardized regression coefficient $(a)$ and the standard error $\left(s_{a}\right)$ of the relationship between the independent variable and mediating variable, and the unstandardized regression coefficient $(b)$ and standard error $\left(s_{b}\right)$ of the path from the mediating to the dependent variable. Table 8 below describes the data and result of Sobel test. The $z$-value is 2.367 (significant in $p<0.05$ ).

\section{CONCLUSION}

The findings of this study show that meaningful access to ICT comprises more than merely providing computers and internet access. Access to ICT rather embedded in a complex array of factors not just physical resources, but also human and social resources. Literacy and capability must also be taken into account if meaningful access to new technologies is to be provided. In other words, overcoming the problem of digital divide is not only by providing physical access to computers and connectivity but also by access to the additional resources that allow people to use technology well. Warschauer (2003) states that the understanding of digital divide as a binary divide between those who have access to ICT and have-not is inaccurate because it fails to value the social resources that diverse groups bring to the table.

Overall, this research yields two theoretical as well as practical contributions. First, this research underlines the importance of CSE, which acts as a partial mediator. In addition to provide the access to e-government systems, it is also important to improve capability to utilize ICT by the citizens. The government should provide and facilitate education for its citizens in using the ICT in general and particularly e-government systems.

Second, this research is significant in the sense that it provides understanding on digital divide. The results provide a foundation to understand the relationships between the access to ICT and CSE, and their impact on e-government use as proposed in the research model. Government may use the findings as the foundation to establish a more comprehensive policy in resolving the issue of digital divide as well as the policy to enhance e-government readiness. More attention should be paid to females, citizens in the remote area, people in age groups of 40 and above, and those who have low educational attainment in opening the access as well as educating to use e-government systems. The e-Government Readiness Survey by United Nations showed that implementation of egovernment systems in Indonesia was in status quo. Therefore, comprehensive and strategic policies to improve e-government system are needed by the government Indonesia.

Table 8: Sobel test

\begin{tabular}{|c|c|c|c|c|c|}
\hline & \multicolumn{2}{|c|}{$\mathbf{X} \rightarrow \mathbf{M}$} & \multicolumn{2}{|c|}{$\mathbf{M} \rightarrow \mathbf{Y}$} & \multirow{2}{*}{ z-value } \\
\hline & $A$ & $s_{a}$ & $b$ & $s_{b}$ & \\
\hline Access - CSE - Use & 0.851 & 0.025 & 0.337 & 0.142 & $2.367^{*}$ \\
\hline
\end{tabular}




\section{REFERENCES}

Agarwal, R., A. Animesh, and K. Prasad. 2009. Social interactions and the digital divide: Explaining variations in internet use. Information Systems Research 20 (2): 277-294.

Bandura, A. 1977. Self-efficacy: Toward a unifying theory of behavioral change. Psychological Review 84 (2): 191-215. . 2001. Social cognititve theory: An agentic perspective. Annual Review of Psychology 52: 1-26.

Baron, R. M., and D. A. Kenny. 1986. The moderator-mediator variable distinction in social psychological research: Conceptual, strategic, and statistical considerations. Journal of Personality and Social Psychology 51 (6): 1173-1182.

Coco, A., and L. Jolly. 2003. Transformation starts at home: Understanding ereadiness in a local community. In Closing the Digital Divide: Transforming Regional Economies and Communities with Information Technology, ed. S. Marshall, W. Taylor and X. Yu, 2743. Westport, Connecticut: Praeger Publishers.

Compeau, D., C. A. Higgins, and S. Huff. 1999. Social cognitive theory and individual reactions to computing technology: A longitudinal study. MIS Quarterly 23 (2): 145-158.

Davison, R. M., C. Wagner, and L. C. Ma. 2005. From government to egovernment: A transition model. Information, Technology and People 18 (3): 280-299.

DeLone, W. H., and E. R. McLean. 2003. The DeLone and McLean model of information systems success: A ten-year update. Journal of Management Information Systems 19 (4): 9-30.

Dewan, S., D. Ganley, and K. L. Kraemer. 2005. Across the Digital Divide: A Cross-Country Multi-Technology
Analysis of the determinants of IT Penetration. Journal of the Association for Information Systems 6 (12): 409432.

Dewan, S., and F. J. Riggins. 2005. The Digital Divide: Current and Future Research Directions. Journal of the Association for Information Systems 6 (12): 298-337.

Gefen, D., D. W. Straub, and M.-C. Boudreau. 2000. Structural equation modeling and regression: Guidelines for research practice. Communications of the Association for Information Systems 4 (7): 1-77.

Hair, J. F., C. M. Ringle, and M. Sarstedt. 2011. PLS-SEM: Indeed a silver bullet. Journal of Marketing Theory and Practice 19 (2): 139-151.

Hsieh, J. P.-A., A. Rai, and M. Keil. 2009. Addressing Digital Inequality for the Socioeconomically Disadvantaged Through Government Inititatives: Forms of Capital That Affect ICT Utilization. Information Systems Research Article in Adv.: 1-24.

Jorgansen, D. J., and S. Cable. 2002. Facing the challenges of e-government: A case study of the city of Corpus Christi, Texas. Advanced Management Journal 67 (3): 1-7.

Marakas, G. M., M. Y. Yi, and R. D. Johnson. 1998. The multilevel and multifaceted character of computer self-efficacy: Toward clarification of the construct and an integrative framework for research. Information Systems Research 9 (2): 126-163.

Rahman, A., and M. Quaddus. 2012. Australasian Conference on Information Systems, Qualitative investigation of digital divide in Indonesia: Toward a comprehensive framework. Geelong, Victoria, Australia: Deakin University. http://dro.deakin.edu.au/eserv/DU:300 49100/rahman- 
qualitativeinvestigation-2012.pdf (accessed

Schuppan, T. 2009. E-Government in developing countries: Experiences from subsaharan Africa. Government Information Quarterly 26: 118-127.

Sobel, M. E. 1982. Asymptotic confidence intervals for indirect effects in structural equation models. Sociological Methodology 13: 290-312.

Srivastava, S. C., and T. T. Teo. 2007. EGovernment Payoffs: Evidence from Cross Country Data. Journal of Global Information Management 15 (4): 2040.

Taylor, S., and P. A. Todd. 1995. Understanding information technology usage: A test of competing models. Information Systems Research 6 (2): 144-176.

UN. 2010. E-Government Survey 2010: Leveraging e-Government at a Time of Financial and Economic Crisis. New York: United Nations.
Warren, M. 2007. The digital vicious cycle: Links between social disadvantage and digital exclusion in rural areas. Telecommunications Policy 31: 374-388.

Warschauer, M. 2003. Technology and Social Inclusion: Rethinking the Digital Divide. Masssachusetts: The MIT Press.

Wei, K.-K., H.-H. Teo, H. C. Chan, and B. C. Tan. 2010. Conceptualizing and Testing a Social Cognitive Model of the Digital Divide. Information Systems Research Article in Adv.: 1-21.

Wold, H. 2006. Partial Least Squares. In Encyclopedia of Statistical Sciences, edited by S. Kotz. Hoboken, New Jersey. John Wiley \& Sons.

Ynalvez, M., and W. Shrum. 2006. International training and the digital divide: Computer and email use in the Philippines. Perspectives on Global Development and Technology 5 (4): 277302. 